\title{
A simple scenario for stygobitization in Stenobermuda Schultz, 1978 (Isopoda Asellota Stenetriidae), with description of a new species from Andros Island, Bahamas
}

\author{
Lazare Botosaneanu * and Thomas M. Iliffe **
}

\begin{abstract}
SUMMARY
Description of a new stygobitic and troglomorphic species of Stenobermuda from a Blue Hole in the Bahamas, is an opportunity for speculation about hypogean colonization by this and by another cave- dwelling species from Bermuda, starting from populations of a widely distributed Western Atlantic shallow water marine species.
\end{abstract}

\section{INTRODUCTION}

Gnathostenetroidoidea Kussakin, 1967, and Stenetiloidea Hansen, 1905, are two of the four superfamilies in which Isopoda: Asellota are presently divided These two superfamilies are considered as being the most primitive Asellota.

Despite much progress achieved in study of diversity in the two superfamilies, incertitude still reigns concerning their characterization and delimitation, the generic limits and the relationships between genera, and even on author names conflicting opinions were published (most of the papers in the References, and several more, would have to be quoted here in support of this statement). For example, genus Stenobermuda was described in Stenetriidae (Schultz, 1978) but transferred to Gnathostenetroididae by Kensley (1994). In our opinion, the male pleopodal arrangement in species of this genus matches better the pattern shown for Stenetrioidea in Wägele (1983: Fig. 4) and in Kensley \& Schotte (1989: Fig. 34and not the diagnoses in this last publication, which sometimes are at strong variance with this figure), and we maintain Stenobermuda in Stenetriidae. Much evidence from the revision of Stenetriidae by Serov \& Wilson (1995) clearly supports this decision.

* I.S.P. / Zoölogisch Museum, University of Amsterdam, Plantage Middenlaan 64, 1018 DH Amsterdam.

** Dept. of Marine Biology, Texas A. \& M. University, Galveston, TX 77553, U.S.A. 
Representatives of the two superfamilies are in their overwhelming majority marine, with the centre of gravity in shallow waters. Quite a few are known to have colonized subterranean waters in karst or in porous habitats, and in some cases the Crenal (listed, with various information, in Henry, Lewis \& Magniez, 1986; subsequently described were: Stenobermuda iliffei Kensley, 1994; Caecostenetroides ruderalis Stock \& Vonk, 1990; and C. ascensionis Vonk \& Stock, 1991).

The present paper is a contribution to the knowledge of stygobitization in primitive Asellota (see Conclusions).

\section{Stenobermuda mergens n.sp.}

Figs. 1-9

\section{Materiai and locality}

Male holotype from Conch Sound Blue Hole, Andros Island, Bahamas. Collected by diving (6.IV.1996, by Brian Kakuk) with plancton net in $26 \mathrm{~m}$ water depths at $750 \mathrm{~m}$ penetration into the cave. A series of appendages missing or broken. Were dissected for study only those appendages strictly necessary for describing the new species (dissecting more would have resulted in completely destroying the unique available specimen). Deposited in the Zoological Museum of the University of Amsterdam.

\section{Description of male}

Length (from tip of rostrum to end of pleotelson): $3.2 \mathrm{~mm}$. Completely depigmented. Eyes (ommatidia) absent. Ratio body length/maximal width (being that of pereionites II and III) slightly exceeding 3.5.

Distal margin of cephalon with triangular, not very acute, rostrum; frontal processes attenuate, anterolateral processes acute, well developed but much shorter than rostrum. The longest pereionites are II and III; pereionites I-III with anterolateral corners pointed and directed anteriad; pereionite IV with small obtuse anterolateral corners followed posteriad by a distinct emargination; pereionites V-VI laterally very obtuse; pereionite VII with acute posterolateral corners directed posteriad. Two very small free pleonites. Pleotelson like in the two already described Stenobermuda (but also like in some Stenetrium), relatively broad, distal margin slightly sinuous, moderately produced (obtuse). Uropods missing.

Maxillipedal endite with only two very characteristic coupling hooks looking like crosses, on its straight median margin; distal margin with 7 
spines, all simple, arranged like in Fig. 3. Maxillipedal palp typical for Stenobermuda.

Carpus of gnathopod with row of some 10 strong setae on internal margin. Propodus distally strongly widening (distal margin only slightly shorter than internal margin, and with a hyaline "blade" along most of its length); on distal margin ("cutting edge") 7 spines - that in the internal corner by far the strongest-; on internal margin (palm) 5 spines, all spines finely pectinate. Pereiopod II (and following): propodus ending in strong conical projection on which a pair of fine setae are inserted.

Pleopods I with very small (i.e.: short and narrow) common protopodite; they form an operculum covering pleopods II and have relatively numerous short setae along their lateral margins.

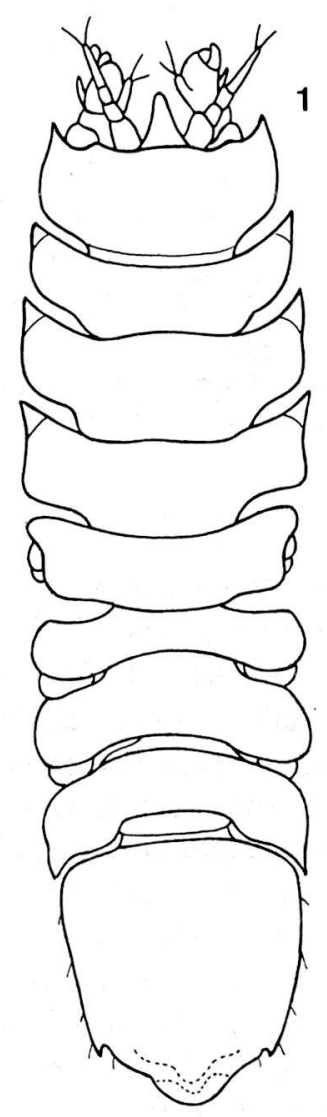

Fig. 1 - Stenobermuda mergens $\mathrm{n}$. sp., male holotype: habitus. 


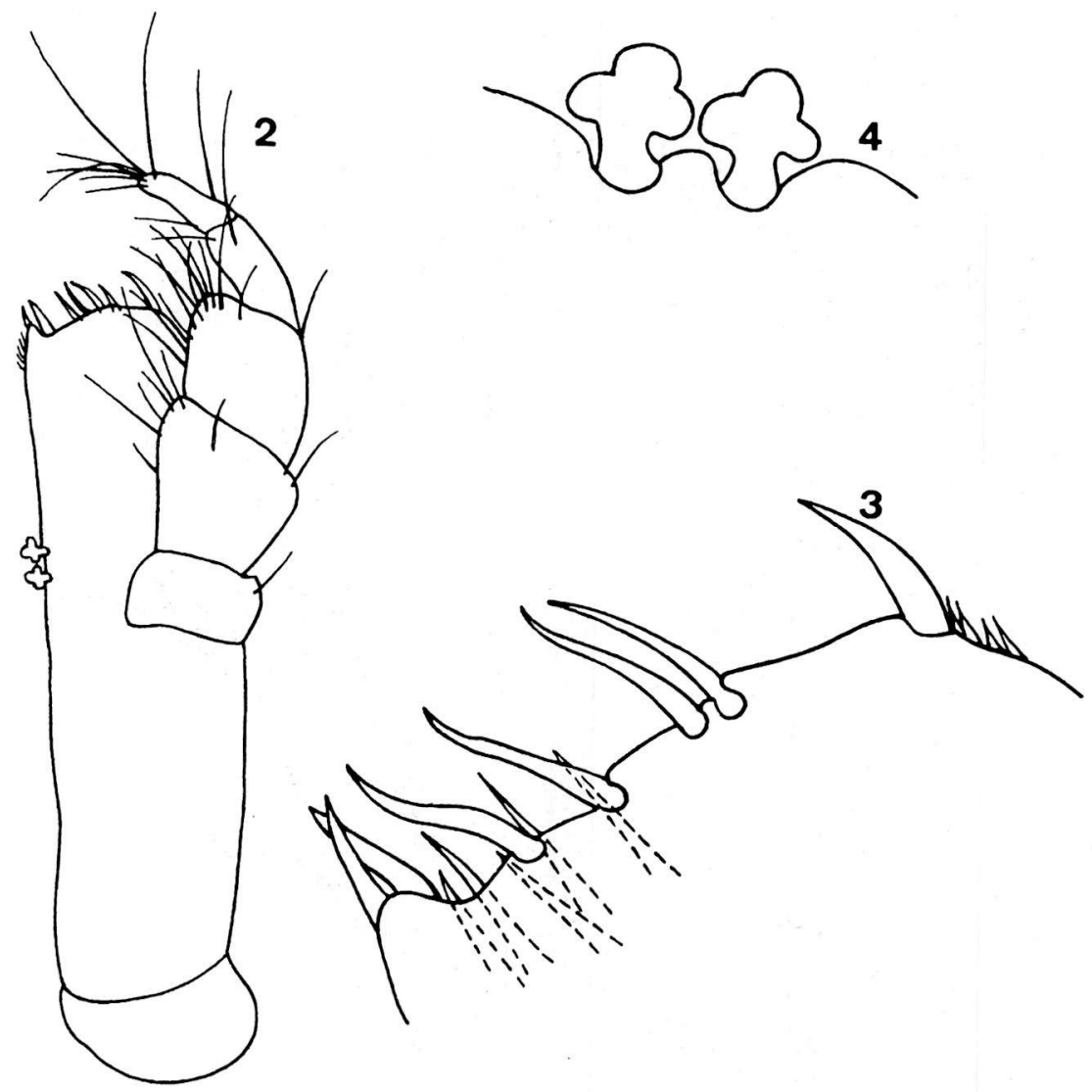

Figs. 2-4 - Stenobermuda mergens n.sp., male holotype: left maxilliped, without the epipodite; distal margin of its endite; and coupling hooks ( 3 and 4 more strongly magnified than 2 ).

The very small pleopods II with uniarticulate exopodite ("a" in Fig. 7) having the shape of a parallelogram, slightly emarginate distally, with long subapical seta and serrate internal margin. Copulatory endopodite biarticulate, strongly flexed, 1st article swollen, 2nd article of very complex structure: anteapical part ("b") widened and bilobed, apically with two appendages: lower one ("c") a darker, slender "spine" with shorter "tooth" near its root, and with apex surrounded by a hyaline blade; upper one ("d") broadly oval, with small, hyaline, wrinkled "crown".

Pleopods III: endopodite much more slender than the biarticulate exopodite, tapering towards the truncate apex on which four plumose setae are inserted; both articles of exopodite strongly widened. 


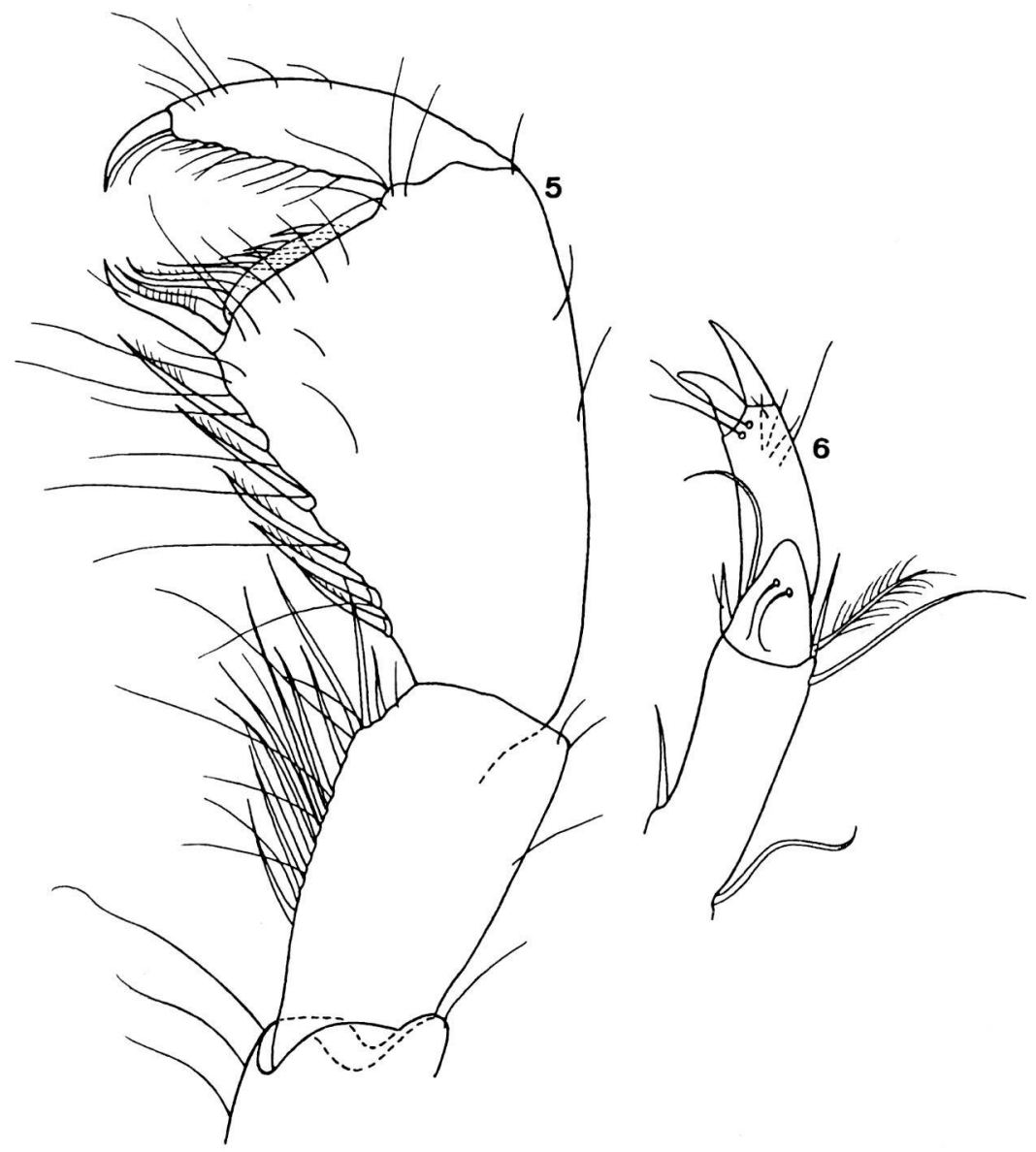

Figs. 5-6 - Stenobermuda mergens n.sp., male holotype: left gnathopod from merus on, and apical part of pereiopod II (6 more strongly magnified than 5).

\section{Comparisons}

The new species clearly belongs to genus Stenobermuda Schultz, 1978, in which two species were already described: S. acutirostrata Schultz, 1978, and S. iliffei Kensley, 1994 (according to Kensley, 1994 "It is probable that several species described under Stenetrium are actually representatives of Stenobermuda"; and in Serov \& Wilson, 1995, the South African marine littoral Stenetrium syzygus Barnard, 1940, is transferred to Stenobermuda). In what follows we shall mention only characters for which comparison with the published descriptions and illustrations shows clear differences. 


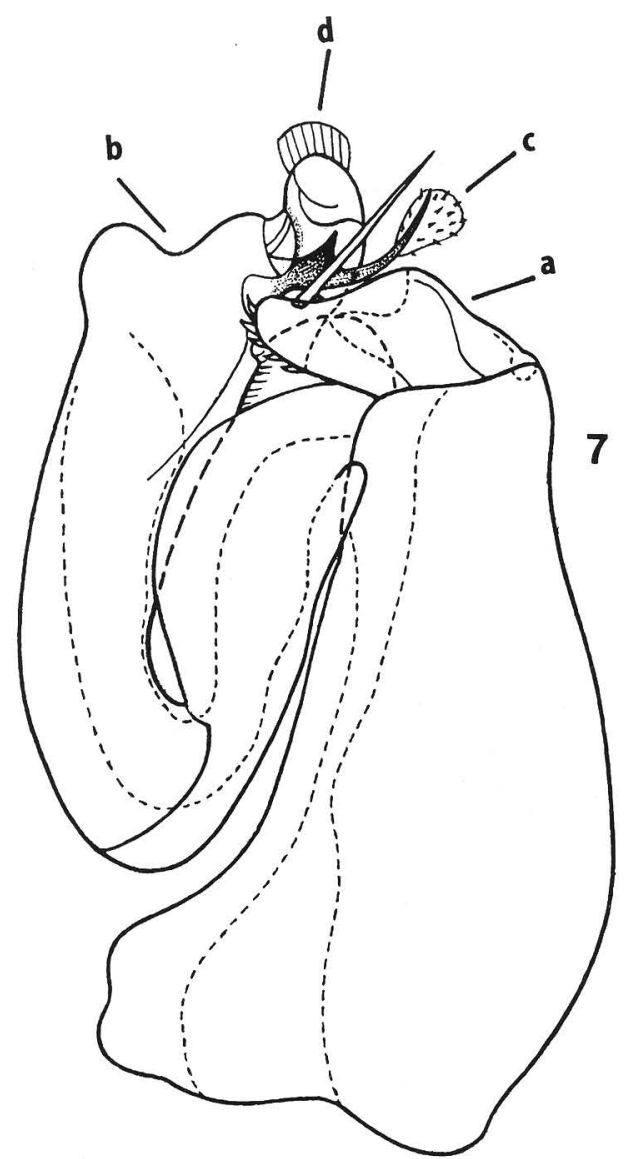

Fig. 7 - Stenobermuda mergens n.sp., male holotype: right pleopod II.

From $S$. acutirostrata the new species differs in: the smaller size; the complete depigmentation (however, in the original description of acutirostrata we read "Pigmentation light if at all"); the anophtalmy; a less pointed rostrum and shorter anterolateral processes of cephalon; the blunt lateral ends of pereionites IV-V (and possibly other details of the pereionites); the relatively broad and distally less produced pleotelson; the very distinctive coupling hooks of the maxilliped endite; the uniarticulate exopodite of pleopod II (this is illustrated - but not described - as biarticulate in acutirostrata), as well as details of its endopodite (although - compare our Fig. 8 with Fig. 3 in Schultz, 1978 - there seems to be some similarity in the structure of its apical appendages). 

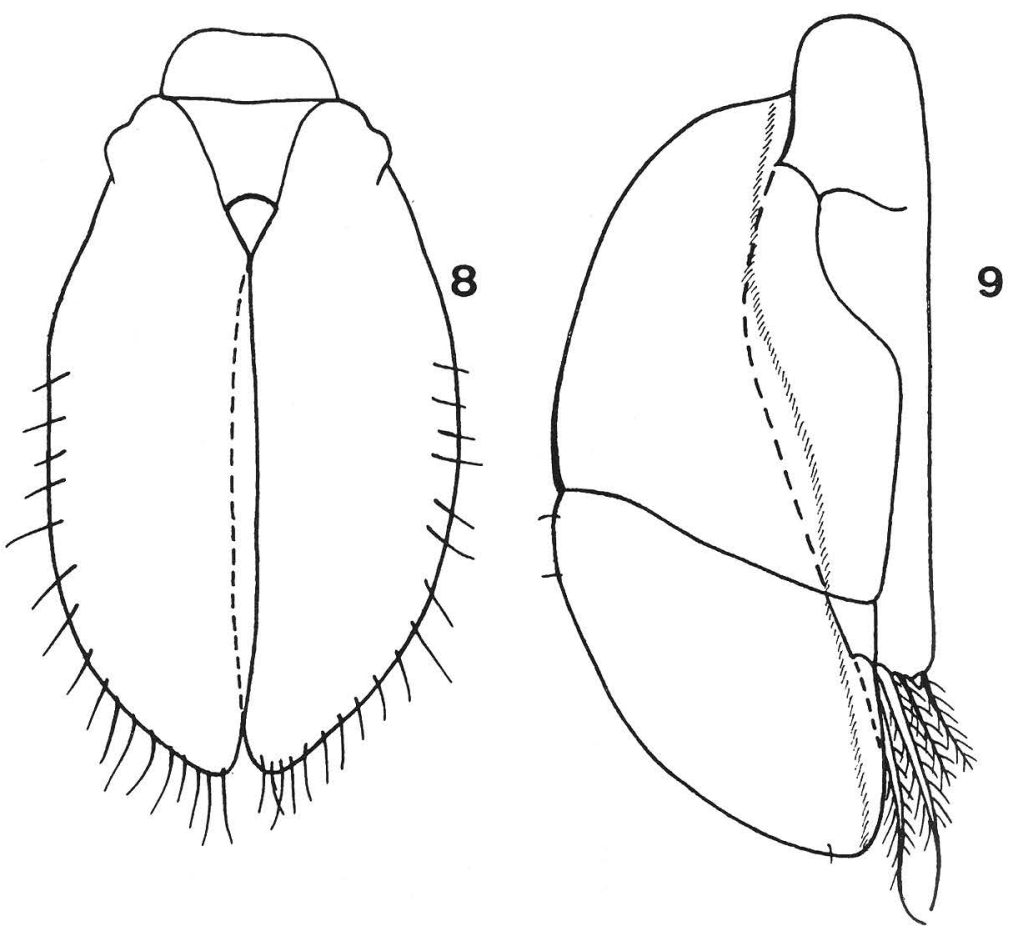

Figs. 8-9 - Stenobermuda mergens n.sp., male holotype: pleopods I, and right pleopod III (8 more strongly magnified than 9 ).

From S. iliffei, S. mergens n.sp. can be distinguished by: the anophtalmy; the very distinctive coupling hooks of the maxillipedal endite, and the very different armature on its distal margin; the distinctly more strongly widened gnathopod propodus and the more numerous strong setae on the internal margin of its carpus; the strong conical projection at the apex of pereiopod II (and following) propodus; the smaller common protopodite of pleopods I; the shape of the exopodite of pleopod II (however, a similarity seems to be the fact that also in S. iliffei the exopodite seems to be uniarticulate: Fig. $10 \mathrm{C}$ in Kensley, 1994); the abundantly different structure of the two apical appendages of pleopod II endopodite.

\section{Derivatio nominis}

The specific name was coined from (Lat.) mergo $=$ to dive, alluding to the fact that the specimen, caught by diving, belongs to a species "diving" in the depths of Blue Holes. 


\section{CONCLUSIONS}

Stenobermuda acutirostrata, S. iliffei, and S. mergens n.sp. are doubtless closely related species. S. acutirostrata was described (Schultz, 1978) from the South shore of Bermuda, from "a bottom of sand and rocks at $90 \mathrm{~m}$ ". It was rediscovered (Schotte, Heard \& Kensley, 1991) in two localities in the Caicos Islands: "Rack Cay, sponge washings" and "Pine Cay, inside fringing reef, rubble- sand substratum, $4-5 \mathrm{~m}$ ". Meagre as it is, the available evidence shows that this is a shallow water species widely distributed in the Western Atlantic. It is lightly pigmented and has apparently eyes consisting of some 5 ommatidia. S. iliffei is known (Kensley, 1994) from Walsingham Cave, Bermuda, where - judging from the number of collected specimens - certainly an important population is present; the species is oculate (eyes consisting of only 4 ommatidia) and probably a relatively recent subterranean colonist. S. mergens n.sp., completely depigmented and anophtalmous, was collected from the depths of a Blue Hole of Andros Island, Bahamas. It is practically certain that $S$. iliffei and S. mergens are hypogean offshoots of different populations of $S$. acutirostrata; we predict that other populations of these two species, and possibly also other closely related subterranean-adapted species will be discovered in hypogean habitats inside the distribution area of the marine species. The colonization of subterranean aquatic biotopes by shallow water marine elements in Gnathostenetroidoidea and Stenetrioidea is considered (Wägele, 1990) as being a general phenomenon.

The stygobiological literature abounds in examples supported by serious evidence (from morphology, distribution, and ecology) of several closely related stygobitic/troglomorphic species being apparently offshoots - of synchronic or asynchronic origin - from different populations of a recent epigean species. Cladists could to their profit ponder over this matter; the existence of such "bushes" contradicts a central dogma of cladistics: the universality of dichotomous branching as phylogenetical scenario (Hoelzer \& Melnick, 1994; Kolibác, 1997).

\section{ACKNOWLEDGEMENTS}

We express thanks to Dr. Nicole Coineau (Banyuls-sur-Mer) and to Prof. Dr. J.-W. Wägele (Bochum) for various information. We also thank Brian Kakuk (Caribbean Marine Research Center) for offering to the second author the specimen here described.

\section{REFERENCES}

CARPENTER, J.H. \& G.J. MAGNIEZ. 1982. Deux Asellotes stygobies des Indes Occidentales: Neostenetroides stocki n. gen., n. sp., et Stenetrium sp. Bijdr. Dierk. 52(2): 200-206. 
HENRY, J.-P., J.J. LEWIS \& G. MAGNIEZ. 1986. Isopoda: Asellota: Aelloidea, Gnathostenetroidoidea, Stenetrioidea. Pp. 434-464. In: BOTOSANEANU, L. (ed.), Stygofauna Mundi, Brill-Leiden.

HOELZER, G.A. \& D.J. MELNICK. 1994. Patterns of speciation and limits to phylogenetic resolution. Tree 9 (3): 104-107.

KENSLEY, B. 1994. Records of shallow water marine isopods from Bermuda with descriptions of four new species. J. Crust. Biol. 14(2): 319-336.

KENSLEY, B. \& M. SCHOTTE. 1989. Guide to the marine isopod crustaceans of the Caribbean. Smithsonian Institution Press, Washington D.C. and Lendon. Pp. 1-308 (Asellota: pp. 73-106).

KOLIBÁC, J. 1997. Dichotomy versus polytomy: a null hypothesis. Acta Mus. Moraviae, Sci. Nat. 81 (1-2): 411-418.

SCHOTTE, M., R.W. HEARD \& B. KENSLEY. 1991. Studies of the Crustacea of the Turks and Caicos Islands, British West Indies. III. Records of marine Isopoda from Pine Cay, Fort George Cay, Water Cay, and adjacent waters. Gulf Research Reports, 8(3): 251-257.

SCHULTZ, G.A. 1978. A new Asellota (Stenetriidae) and two, one new, Anthuridea (Anthuridae) from Bermuda (Crustacea, Isopoda). Proc. Biol. Soc. Wash. 91(4): 904-911.

SEROV, P.A. \& G.D.F. WILSON. 1995. A review of the Stenetriidae (Crustacea: Isopoda: Asellota). Records of the Australian Museum 47: 39-82.

STOCK, J.H. \& R. VONK. 1990. Stygofauna of the Canary Islands 15. Marine interstitial Isopoda Asellota of the superfamily Gnathostenetroidoidea. Cahiers de Biologie Marine, 31: 5-24.

VONK, R. \& J.H. STOCK. 1991. Caecostenetroides ascensionis n.sp., a blind marine interstitial isopod (Asellota Gnathostenetroidoidea) from Ascension island, South Atlantic. Tropical Zoology 4: 89-98.

WÄGELE, J.-W. 1983. On the origin of the Microcerberidae (Crustacea: Isopoda). Z.f. zool. Systematik u. Evolutionsforschung 21(4): 249-262.

WÄGELE, J.-W. 1990. Aspects of the evolution and biogeography of stygobiontic Isopoda. Bijdr. Dierk. 60(3/4): 145-150. 